\title{
Intellectual property law and the Single Market: the way ahead
}

\section{Florence Hartmann-Vareilles}

Published online: 18 June 2014

(C) ERA 2014

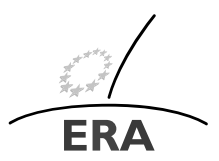

EUROPÄISCHE RECHTSAKADEMIE ACADEMY OF EUROPEAN LAW ACADEMIE DE DROIT EUROPEEN ACCADEMIA DI DIRITTO EUROPEO TRIER - TREVES - TREVIRI

\section{Introduction: Intellectual property as a tool to reach the goals of the single market}

The value of intellectual property as a way for companies to generate income through the licensing, sale, or commercialisation of products or services protected as intellectual property is now well established. At the macro-economic level, the importance of intellectual property is also recognised. As underlined in the 2011 Communication from the European Commission, ${ }^{1}$ appropriate protection of intellectual property is an essential factor for sustainable and integrative growth in the European Union and for the competitiveness of the European economy. Intellectual property is therefore seen as a key element in order to reach the targets of growth and employment of the Single Market. According to the study carried out in 2013 by the European Patent Office (EPO) and by the Office for Harmonization in the Internal Market (OHIM), acting through the European Observatory on Infringements of Intellectual Property rights, IPR-intensive industries ${ }^{2}$ are shown to have generated almost $26 \%$ of all jobs in the

\footnotetext{
${ }^{1}$ Communication from the European Commission, $\operatorname{COM}(2011) 287$ final from 24.5.2011 on A Single Market for Intellectual Property Rights: Boosting creativity and innovation to provide economic growth, high quality jobs and first class products and services in Europe.

${ }^{2}$ IPR-intensive industries are defined as those having an above-average use of IPR per employee. See for more information: Study on Intellectual property rights intensive industries: contribution to economic performance and employment in the European Union, Industry-Level Analysis Report, September 2013; A joint project between the EPO and the OHIM, at: http://ec.europa.eu/internal_market/ intellectual-property/docs/joint-report-epo-ohim-final-version_en.pdf.
}

F. Hartmann-Vareilles, Head of Section for Business Law ( $\square)$

Academy of European Law (ERA), Trier, Germany

e-mail: fhartmann@era.int 
EU during the period 2008-2010 and almost $39 \%$ of total economic activity (GDP) in the EU.

It comes, therefore, as no surprise that the protection of intellectual property rights has been the subject of major EU and national legislative developments within the last couple of years. Recent EU initiatives include, among others, the adoption in 2012 of a Directive setting out common rules on the digitisation and online display of so-called orphan works, ${ }^{3}$ a Regulation in 2013 reinforcing customs enforcement of intellectual property rights ${ }^{4}$ and, in 2014, a Directive on collective rights management and multi-territorial licensing of rights in musical works for online uses. ${ }^{5}$ Recent activities aimed at adapting the EU legal framework for copyright to the development of new technologies are still ongoing. Two well-advanced initiatives in the area of industrial property law are worthy of further elaboration in this editorial. The first concerns the creation of a unitary patent protection in the European Union and the second is the reform of the trade mark system.

\section{The breakthrough on the "patent package": between flexibility and asymmetry}

2.1 The unitary patent with unitary effect: bringing new opportunities for patent protection in the European Union

Up to now, inventions can be protected in Europe either by national patents granted by the competent national authorities, or by European patents granted centrally by the European Patent Office. The most remarkable, innovative EU political development for industrial property rights is undoubtedly the adoption of a legal framework ${ }^{6}$ for the creation, of a unitary patent title within the European Union. Two Regulations adopted in 2012 under Article 118 TFEU will soon ensure uniform protection for an invention across the Member States on a one-stop shop basis. This ground-breaking new system, adopted at the end of last year after lengthy and often contentious discussions on language regime and translation costs, creates an innovative but asymmetric legal construction. This complex legal scheme is characterised by a unitary patent title created by the European Union, which will be granted by the European Patent Office (EPO) as a non-EU institution, the validity of which will be put under the scrutiny of a centralised supra-national Court, created on the basis of an international Agreement.

\footnotetext{
${ }^{3}$ Directive 2012/28/EU setting out common rules on the digitisation and online display of so-called orphan works (OJEU, L 299, 27.10.2012).

${ }^{4}$ Regulation (EU) No. 608/2013 of 12 June 2013 concerning customs enforcement of intellectual property rights and repealing Council Regulation (EC) No. 1383/2003 (OJEU, L 181, 29.06.2013).

${ }^{5}$ Directive 2014/26/EU on collective management of copyright and related rights and multi-territorial licensing of rights in musical works for online use in the internal market (OJEU, L 84, 20.03.2014).

${ }^{6}$ Regulation (EU) No. 1257/2012 of the European Parliament and of the Council of 17 December 2012 implementing enhanced cooperation in the area of the creation of unitary patent protection (OJEU L 361, 31.12.2012) and Regulation (EU) No. 1260/2012 of 17 December 2012 implementing enhanced cooperation in the area of the creation of unitary patent protection with regard to the applicable translation arrangements (OJEU L 361, 21.12.2012).
} 
In line with the Single Market objectives, the system aimed at fostering innovation and competitiveness by reducing current patent fees and translation costs will also provide for more flexibility and legal certainty in the judicial decision-making process. Unitary patent protection will only be offered as an option to the applicant, who will still be entitled to avail, as an alternative, of the traditional national patent or the well-established European patent (constituted by a bundle of national patents) having the effect of a national patent within the designated contracting states.

As the new system will provide for coexistence between national patents, European patents and European patents with unitary effect, patent filing will become an ever more important strategic issue for patent holders, most of all for big companies engaged in cross-border activities. A European patent with unitary effect will only be limited, transferred, revoked or lapse in respect of all the participating Member States. The patentee will therefore have to apply for a European patent with unitary effect when he is sure about the strength of his patent because this filing entails the risk at a later stage of a court invalidation that will have effect across all the contracting Member States. Hence, should a patent holder have any doubt as to the validity of his patent, he may well be better advised to choose protection in selected Member States.

Although the coexistence provides for more flexibility, it is less certain, however, that the scheme will be advantageous for all. Small and medium size enterprises (SMEs) with smaller patent portfolios might still prefer, for reasons of costs and internal organisation, to chose national patent filing or pure European patent filing within a limited number of designated Member States.

The unitary patent with unitary effect is, however expected, to be simpler and less costly than what is offered to patent holders under the current system. The costs for translation will be reduced as the patent holder will be able to file in any language. If he does not file in one of the official languages of EPO (English, French or German), a translation in one of these languages will have to be made. The language of the translation becomes the language of procedure before the EPO. Measures to compensate the translation costs of patents filed in a language other than one of the three official languages of the EPO, will be offered to SMEs, universities or public research centres as well as individual inventors. Consequently, by limiting the compensation to such actors it would be possible to avoid certain financial burdens of the system.

The compensation scheme will be financed by the payment of renewable fees payable each year to the EPO instead of payment of annuities to the selected Member States. The new procedure will hence be simpler for patent holders who will not be obliged anymore to adapt to administrative requirements which can vary from one Member States to another. However, the level of the fees and renewable fees to be paid has not yet been decided by the EPO select committee. Some patent holders have legitimate concerns that, due to the fact that the level of the fees is based on the functioning costs, they will, in fact, be much higher than what has always been praised as being a major benefit of the new system. The level of the fees will therefore have a crucial impact on the efficacy of the new patent scheme. It will have to be high enough in order to cover the costs of implementation of the unitary patent, but if fixed too high, the European patent with unitary effect will lose its attractiveness with the risk of becoming a sleeping beauty. 
The complexity of the new system due to its asymmetry is undeniable. Adopted in the framework of enhanced cooperation as provided for in Article 20 TEU and Articles 326-334 TFEU, both EU Regulations creating a unitary patent title and its translation arrangements are only binding on the 25 participating Member States, generating a "multi-speed patent protection" in the European Union. Enhanced cooperation is certainly an efficient EU instrument in order to overcome paralysis, where a proposal is blocked by the veto of a small group of Member Sates not wishing to be part of the initiative, but it can have a crucial impact in practice. A double speed system might impair the Internal Market by distorting competition and creating a barrier in trade between States. Should Italy and Spain continue to object to joining the system in the near future, companies with based in those Member States will have to bear higher costs vis à vis their EU competitors, since if they want to obtain protection in several Member States they will still have to manage a bundle of national patents with their own administrative rules including diverging rules on renewable fees in the respective Member States. Furthermore for matters not covered by EU law, the provisions of the unitary patent agreement and national law, including rules of private international law will apply, rendering the procedural rules very complex to use in practice. ${ }^{7}$

The EU Regulations entered into force on 20 January 2013. However, they will only apply from the date of entry into force of the Agreement on a Unified Patent Court.

\subsection{The Unified Patent Court as a unique litigation system in Europe}

Currently, national courts are competent to decide on the infringement and validity of European patents. This gives rise in practice to a number of difficulties when a patent proprietor wishes to enforce a European patent or when a third party seeks the revocation of a European patent in several countries including high costs of the proceedings and the risk of divergent decisions.

The Agreement on a Unified Patent Court (AUPC), signed on 19 February 2013, will set up the Court system and aims to provide remedies to these disparities. As long as it will be ratified by at least thirteen participating Member States, the European patent with unitary effect will become available. Of the thirteen ratifications that are needed to bring the UPC (Unified Patent Court) into force, those of the UK, France and Germany are needed. Article 89(1) of the UPC Agreement provides that the Agreement cannot enter into force prior to the entry into force of the amendments to the Brussels I Regulation regulating the relationship between both instruments. The European Commission has therefore adopted, in the summer of 2013, a proposal to amend the current legal framework on jurisdiction and the recognition and enforcement of judgments in civil and commercial matters. ${ }^{8}$

\footnotetext{
${ }^{7}$ For a critical analysis of the new patent system, see the document prepared by the Max-Planck Institut for Intellectual Property and Competition Law: The Unitary Patent Package: Twelve Reasons for Concern: http://www.ip.mpg.de/files/pdf2/MPI-IP_Twelve-Reasons_2012-10-17.pdf.

${ }^{8}$ Brussels, 26.7.2013, COM(2013) 554 final, Proposal for a Regulation amending Regulation (EU) No. 1215/2012 on jurisdiction and the recognition and enforcement of judgments in civil and commercial matters.
} 
For the moment, Poland, Croatia and Spain did not sign the agreement whereas Italy, which did not join the enhanced cooperation mechanism, decided, however, to sign the agreement. It is predictable that some Member States will opt for ratification by Parliamentary vote requiring unanimity in some instances. Some other countries might choose or might even be obliged to seek ratification via a public referendum. Given the past experience of the European Union in relation to the European Constitution in 2005 when the proposal was rejected by voters in the Netherlands and France, the risks associated with popular votes should not be underestimated and they always bear the risk of being subjected to Euro-scepticism, independent of the question raised.

The UPC will apply for traditional European patents and for European patents with unitary effect. The Court will have a first instance with local divisions in the participating Member States, regional divisions for some group of Member States wishing to adopt it, and a central division located in Paris with branches in $\mathrm{Mu}-$ nich (for mechanical engineering) and London (for chemistry, pharmaceuticals and human necessities). The second instance with a common Court of Appeal will be located in Luxembourg. The new UPC addresses therefore the problems of the current system which obliges litigants to enforce their bundle national patents before national Courts, and who bear the risk of paying high procedural costs and obtaining diverging national decisions for the same type of cases. Responding to the need expressed by litigants to obtain rapid decisions, primarily in cases involving high economic stakes, the AUPC imposes strict procedural deadlines on parties in order to ensure that decisions are adopted within a maximum of one year. It remains to be seen how litigants will cope with these strict deadlines, particularly where complex and technical patent cases will be concerned.

Any panel of the UPC will have a multinational composition of judges. This pool will be composed of technically and legally qualified judges appointed by the Administrative Committee of the UPC. The standard of competence of these judges will be crucial in order to create trust in the litigation system. Appointed judges will therefore have to be offered a high standard of training. A Budapest based Training Centre for the UPC officially opened in March 2014. The training, which is expected to start in 2015 , will be under the obligation to offer all necessary guarantees of independence and quality in terms of the training being offered, even going far beyond procedural and substantial patent law as judges will be faced with rules of international private law, general questions of European Union law, complex issues related to competition law or supplementary protection certificates and sometimes unclear issues requiring preliminary rulings from the Court of Justice of the European Union (CJEU). Although it is clear that the Court of First Instance and the Court of Appeal may refer questions to the CJEU, it is unclear whether this solely includes questions on the interpretation of EU law or if it will expand to patent infringement cases.

The UPC will have exclusive jurisdiction over traditional European patents, patents with unitary effect and supplementary protection certificates in respect of actions for revocation, requests for preliminary injunctions, declarations of noninfringement and actions or counterclaims for revocation. The Unified Patent Agree- 
ment and the rules of procedure currently under preparation ${ }^{9}$ contain a certain number of rules on language regime, preliminary injunctions, damages and the so called $b i$ furcation procedure which will give judges from a local or regional division seized of an infringement action the option to refer a counterclaim for invalidity to the central division.

One of the key questions raised by future users of the litigation scheme relates to the possibility offered to patent holders to opt-out of the exclusive competence of the UPC for traditional European Patents and for the observance of a transitional period of seven years (extendable for another seven years). Once notified and registered to the Registry of the new Court, the opt-out takes effect for all European bundled patents in all Contracting Member States where this patent has been validated. European patents falling within the scope of an opt-out will be governed by the national law of the Member State for which they have been granted; actions for infringement or revocation will still be brought before these national courts. However, the optout is only applicable if proceedings before the UPC have not started already, which means that as soon as an infringement or revocation action is pending before a national court, the applicant or the proprietor of a European patent will no longer be able to opt-out. This option to opt-out will therefore bring with it new tactical litigation options, especially for patent infringers, as an action for revocation filed with the UPC will block the patent proprietor from opting-out, thereby obliging him to litigate his case before the UPC. It is to be expected that frequent use will be made of the faculty to opt out by patent holders during the transitional period, most of all within the first years of implementation of the litigation system given that the opt-out avoids the risks of exposure to a single revocation action for all Member States.

Moreover, the proceedings before the UPC will be subject to the payment of court fees composed of a fixed fee and a value-based fee, the amount of which is not yet known. Here again, the level of these fees will have a crucial impact on the efficacy of the litigation system and on its attractiveness.

\subsection{Concluding remarks on the patent package}

The new patent litigation system has been broadly welcomed by a majority of patent holders. However, many of them are still not certain that they will immediately opt-in when the agreement comes into force. The decision to opt-in or to opt-out will most probably be taken on a case by case basis and will depend on strategic factors as well as on other crucial factors still to be clarified as to the amount of renewable fees, the qualification of judges, as well as the length of the litigation procedure.

As the result of a compromise, the asymmetric system that will be put in place certainly contains drawbacks and imprecisions, the main difficulty being its complexity in practice, particularly during the transitional period. This is because the UPC, which is only open to EU Member States, will also apply to classic European Patents, whereas EU Member States outside the scope of enhanced cooperation can still choose to be submitted to the ruling of the UPC or not. At the moment, Spain and

\footnotetext{
${ }^{9}$ Revised 16th draft of the Rules of procedure at http://www.unified-patent-court.org/news/72-revised16th-draft-of-the-rules-of-procedure.
} 
Croatia are the two remaining countries which neither participate in the enhance cooperation arrangement nor have they signed the UPC. Whereas Italy does not participate to enhance cooperation, it has decided to sign the UPC. Poland, on the contrary, participates to enhence cooperation but it has not signed the Agreement yet.

As with every new system, time and experience are needed in order to assess its success and failure but its added value is undeniable. Very interesting alternatives to this system had previously been proposed, one of these being the creation of a patent protection system in the European Union which would follow the scheme of what already exists for the Community trade mark (CTM). ${ }^{10}$ However, the historical and political background for the legal protection of trade marks and patents in Europe is very different and adapting the Community trade mark system to patent protection might be too challenging an exercise.

\section{The trade mark system under reform in the European Union}

\subsection{The Community trade mark: a success story in need of fine tuning}

Since its inception more than twenty years ago, the Community trade mark (CTM) system has proved to be very successful. As underlined in the Max-Planck study performed in 2011 at the request of the European Commission, ${ }^{11}$ users of the current CTM system are largely satisfied with the centralised trade mark procedure of registration administered by the Office for Harmonization in the Internal Market (Trade Marks and Designs) (OHIM) in Alicante. As with the new unitary patent system, the legal framework provides for coexistence between national and Community trade marks. The coexistence of the CTM system and the national systems was supplemented in 2004 by the membership of the European Union to the 1989 Protocol to the Madrid Agreement concerning the International Registration of Marks. The European trade mark system has remained essentially unchanged since its adoption and users find it now somewhat outdated. It provides a limited harmonisation of national trade mark systems and does not foresee enough cooperation between national intellectual property offices and OHIM.

In 2007, when addressing the issue of the financial perspectives of OHIM, the Council $^{12}$ emphasised that the establishment of OHIM had been a great success and that it had contributed substantially to strengthening the competitiveness of the EU. However, the Max Planck report nevertheless found that further convergence of trade mark laws and practices in the EU was required. Again, following its policy objectives of fostering innovation and economic growth, in 2013 the European Commission proposed to modernise the trade mark system by making registration more accessible and efficient for businesses in terms of lower costs and complexity, increased

\footnotetext{
${ }^{10}$ See for example the article written by Fernand de Visscher, Juridiction européenne des brevets (Unified Patent Court): il est urgent d'examiner une autre approche, plus réaliste, plus équitable, Propriété industrielle, Revue Mensuelle Lexisnexis jurisclasseur, avril 2012, étude 8.

${ }^{11}$ The entire study from Max Planck Institute for Intellectual Property and Competition Law Munich on the Overall Functioning of the European Trade Mark System published in 2011 can be downloaded at http://ec.europa.eu/internal_market/indprop/docs/tm/20110308_allensbach-study_en.pdf.

${ }^{12}$ Competitiveness Council Conclusions of 21 and 22 May 2007, Council document 9427/07.
} 
speed, greater predictability and legal security. The package is composed of two proposals for a revision of the Regulation on the Community trade mark, for a recast of the Directive approximating the laws of the Member States relating to trade marks and a proposal for a revision of a regulation on fees for the Community trade mark registration. ${ }^{13}$

The first set of proposals concerns institutional changes. If the proposal remains unchanged after the negotiations currently taking place in the different EU instances, the Office for Harmonisation in the Internal Market would in the future be called the "European Union Agency for Trademarks and Designs". This change would result from the modification of terminology in general in the European Union Treaties agreed in Lisbon. The qualification of the current Office as an Agency of the European Union would not be politically neutral. The centralised role of the OHIM for the registration of Community trade marks is reinforced by the fact that national applications of Community trade marks will not be possible any more. The Regulation will now list in considerable detail the tasks of the OHIM, among which its mandate to cooperate with the national intellectual property offices to harmonise practices in the field of trademarks and design. Thus, what is currently already carried out in the Cooperation Fund and the so-called "convergence programs" will now have a legislative foundation. The voting power of the European Commission within the OHIM executive bodies as well as its role in the decision making process is also strengthened.

The second set of proposals is aimed at modernising some provisions of the legal framework and increasing legal certainty. The definition of a trade mark would no longer require graphic representation enabling thus the registration of very unconventional signs like sounds or colours as such. Users who are increasingly inventive in their attempts to register particularly innovative kinds of signs largely welcome the extension of the definition. This might be less of a problem for the OHIM to register this kind of marks, but it is questionable whether all national offices are technically equipped to handle these new types of marks. A crucial point of the reform concerns the reinforcement of trade mark protection against infringement of goods in situations of transit by entitling trade mark owners to prevent third parties from importing into the EU counterfeit goods in transit coming from third countries even if the goods are not actually sold or offered for sale in the EU. Interestingly, the European Commission did not follow the guidelines adopted by the Court of Justice in its decision Philips/Nokia, where the Court held that in order to enable interception of goods in transit, trade mark owners had to prove that the goods are likely to be made available in the European Union, thereby creating a sort of presumption of sale within the European Union. ${ }^{14}$ The proposals will also contain some rules aimed at tackling the purchase of fake goods on the internet by making it possible to seize small consign-

\footnotetext{
${ }^{13}$ COM (2013) 161, 2013/0088/COD, Proposal for a Regulation amending Council Regulation (EC) No. 207/2009 on the Community trade mark, COM (2013) 162, Proposal for a Directive to approximate the laws of the Member States relating to trade marks (Recast). The proposed revision of the Fees Regulation will be adopted by the Commission as an implementing act and therefore requires prior endorsement by the competent Committee on OHIM fees.

${ }^{14}$ Joined Cases C-446/09 and C-495/09, Koninklijke Philips Electronics NV (C-446/09) v Lucheng Meijing Industrial Company Ltd, [2011] ECR I-12435.
} 
ments of goods that amount to an infringement at borders and addressed to private purchasers in Europe.

The third set of proposals is aimed at reaching a greater approximation of substantive law and includes the codification of important case law from the ECJ as to, for example, the classification of goods and services. The latter clarification is seen as a crucial issue for registrants and national intellectual property offices, both of which require more legal certainty when it comes to defining the goods and services for which a registration is sought.

A remarkable set of reforms concerns the extension of the protection afforded to geographical indications. The exclusion from registration of marks which conflict with EU-protected geographical indications or designations of origin is reinforced. Also, the right to oppose the registration of a trade mark based on earlier geographical indications is codified. Besides the already existing legal framework for collective marks, the proposals would allow for the registration of certification or guarantee marks, enabling to some extent more strategic choices to beneficiaries of geographical indications. However, as underlined by Benjamin Fontaine in his article published in this issue, the current proposal still seems to contain loopholes. ${ }^{15}$

A last set of proposals has the double objectives of improving access to registration by offering more tailored trade mark registration and of harmonising trade mark law through a deeper harmonisation of national trade mark laws and an alignment of national procedures with those applied before the OHIM for the Community trade mark. The deletion of ex-officio examination by national offices of relative grounds for refusal for trade mark registration is noteworthy in this context.

\subsection{Concluding remarks on the trade mark reform}

The trade mark system has unquestionably proved to be successful. The objective of the current reform is mainly a fine tuning exercise. It missed, however, an opportunity to clarify still unclear concepts such as the notion of genuine use in trademark law, a concept to which Marianne Grabrucker has dedicated an article published in this issue. ${ }^{16}$ However, a majority of stakeholders are welcoming the Commission's decision to revise the current legislation. In a joint paper published in February 2014, several leading trade marks actors, including ECTA, INTA and Marques, recognised the efforts of both The European Commission and the European Parliament in attempting to meet the evolving needs of users. ${ }^{17} \mathrm{~A}$ few important issues remain controversial nonetheless. Users first advocate for an institutionalisation of their involvement in the decision-making process. The second issue is about the fate of the control of infringing goods in transit, where, despite the improvements proposed by the JURI

\footnotetext{
${ }^{15}$ See in this issue of the ERA Forum, article written by Benjamin Fontaine on "The present and future of the interaction between trade marks and geographical indications in Community law".

${ }^{16}$ See in this issue of the ERA Forum, the article written by Marianne Grabrucker on Genuine Use and the Court of Justice decision in Leno Merken v Hagelkruis, (ONEL/OMEL): a question of facts for the national judge.

${ }^{17}$ Joint paper from BUSINESSEUROPE, AIM, ECTA, ICC-BASCAP, INTA and MARQUES: European trade mark package at: http://62.102.106.140/docs/1/GMFDGMKDKGCGEDOCLHLNOJIDPDWK9DB YTD9LTE4Q/UNICE/docs/DLS/2014-00170-E.pdf.
} 
committee of the European Parliament in its report, it seems that unsatisfactory gaps still remain that prevent the seizure of goods in transit from being a totally efficient means. ${ }^{18}$

As to national intellectual property offices, the majority of them seem to be in favour of this reform which brings a deeper harmonisation in the registration procedures across Europe. One of the main bones of contention, however, concerns the setting of the fees which will in the future be adopted by means of delegated acts of the European Commission, as provided for in Article 290 TFEU. This would mean that Member States would lose control over fees that they currently have via their participation in the so-called regulatory committee.

The European Parliament adopted the reports of its JURI Committee on 25 February 2014, adding a certain number of amendments to the Commission's original proposal. Due to the existence of a number of remaining open questions, including the extent of the powers conferred to the European Commission, the proposals are not expected to be adopted before the second semester 2014.

$18 * * *$ I REPORT on the proposal for a regulation of the European Parliament and of the Council amending Council Regulation (EC) No. 207/2009 on the Community trade mark, (COM(2013)0161C7-0087/2013-013/0088(COD)), Committee on Legal Affairs, Rapporteur: Cecilia Wikström, at: http://www.europarl.europa.eu/sides/getDoc.do?pubRef=-//EP//NONSGML+REPORT+A7-2014-0031+ $0+\mathrm{DOC}+\mathrm{PDF}+\mathrm{V} 0 / / \mathrm{EN}$. 